Wiedza religioznawcza w badaniach politologicznych, red. Bogumił Grott, Olgierd Grott, Wydawnictwo von Borowiecky, Warszawa 2015, ss. 277

\title{
Leszek Zaborowski*
}

Bogumił Grott oraz Olgierd Grott znani są przede wszystkim z pogłębionych studiów dotyczących dziejów i myśli polskiego obozu narodowego. W zredagowanym przez nich tomie, który ukazał się pod tytułem Wiedza religioznawcza $w$ badaniach politologicznych, również nie zabrakło analiz dotyczących tej tematyki. Ich zakres wykracza jednak zarówno poza granice naszego kraju, jak i dziedzinę badań ruchów nacjonalistycznych. Jak podkreślono w słowie wstępnym, analizowane przypadki łączy pozostawanie w obrębie zainteresowań politologii religii. Tak jak podkreślają sami redaktorzy tomu, dość młoda dyscyplina koncentruje się na wpływie pierwiastka religijnego na życie polityczne. Nie trzeba przekonywać, że zrozumienie danego zjawiska z dziedziny polityki bez znajomości obecnych u jego źródeł wartości religijnych czy etycznych okazuje się często-

\footnotetext{
* Uniwersytet Warszawski, Instytut Socjologii.
}

kroć niemożliwe. Autorzy tekstów ukazują na rozmaitych przykładach, w jakim sensie sfera religii oddziałuje na kształt teorii i praktyki politycznej, a czasem wręcz go warunkuje.

Co istotne, w otwierającym tom tekście Bogumił Grott ukazuje, że pomijanie aspektu religijnego $\mathrm{w}$ badaniach politologicznych może uczynić opis nie tyle niepełnym, co wręcz doprowadzić do głębokiego zniekształcenia rzeczywistości. Dokonuje tego na przykładzie wspomnianych już idei polskich nacjonalistów doby międzywojnia, osadzonych jednak w szerszym kontekście antyliberalnych tendencji obecnych w europejskiej myśli tego czasu. Autor wykazuje, iż efektem podobnego zaniedbania ostatecznie okazuje się nie tylko niezrozumienie dogłębnych różnic występujących pomiędzy rozmaitymi nacjonalizmami, ale także powodów, dla których okazywały się mieć tak diametralnie odmienne, historyczne konsekwencje. Religia i etyka kształtują bowiem etos społecz- 
ny, decydujący o podatności bądź niechęci do danych czynów określonych społeczności. W tym sensie wiedza religioznawcza jest warunkiem koniecznym rzetelnych badań politologicznych dotyczących nie tylko teorii, ale i praktyki politycznej. Doskonałą ilustracją może tu być zjawisko antysemityzmu występującego w polskim obozie narodowym przed i w trakcie II wojny światowej. To właśnie w tym przypadku odmienne tło i wpływy religijne okazują się jednym z głównych czynników decydujących o jego odmienności od rasowych koncepcji nazistów, a także wyciąganych z nich praktycznych konsekwencji. Kwestię tę analizuje w swoim tekście Artur Paszko.

Również inne zawarte w tomie artykuły ukazują nam, w jakim sensie wiedza religioznawcza niejednokrotnie okazuje się nieuniknionym punktem wyjścia dla analizy politologicznej. I tak, bez znajomości współczesnego tradycjonalizmu katolickiego nie zrozumiemy genezy i struktury programu chociażby niektórych radykalnych organizacji nacjonalistycznych i konserwatywnych działających w III RP, jak pokazał w swoim tekście Maciej Strutyński. Bez zaś zaznajomienia się z osadzoną w tradycji prawosławia antyokcydentalistyczną myślą rosyjską oraz tradycjonalizmem integralnym nie pojmiemy genezy i kształtu eklektycznej myśli wzbudzającego ostatnio tak wielkie zainteresowanie Aleksandra Dugina, którego dzieła omawia Krzysztof Karczewski.
Nie zabrakło również analizy przypadków, w których doniosłe konsekwencje polityczne okazuje się mieć splot tożsamości narodowej z danym wyznaniem bądź obrządkiem religijnym. Tak było w sytuacji Ukraińców i Cerkwi greckokatolickiej w międzywojennej Polsce, a jest w wypadku rzymskiego katolicyzmu i Polaków na dzisiejszej Białorusi. Jak pokazują w swych tekstach Olgierd Grott i Helena Giebeń, decyzje hierarchii dotyczące języka sprawowanej liturgii czy narodowości proboszczów mogą się okazywać kluczowym narzędziem podtrzymywania lub też rozmywania poczucia przynależności do danej nacji. Co może się niektórym wydawać zaskakujące, w drugim ze wspomnianych tekstów autorka formułuje tezę, iż współczesna polityka katolickich, białoruskich biskupów okazuje się sprzyjać depolonizacji.

Co istotnie, $\mathrm{w}$ tomie nie brakuje także badań nawiązujących do dorobku tych autorów, których prace przyczyniły się do podważenia $\mathrm{z}$ jednej strony przekonania o nieuchronności procesów sekularyzacyjnych, z drugiej zaś tezy o postępującym spadku wpływu religijnych przekonań i wizji świata na kształt sfery polityki. W tekście Rafała Łętochy znajdziemy więc odwołania (wśród wielu innych autorów) do dorobku socjologów takich jak: Jose Casanova, Rodney Stark i Roger Finke, przekonujących w swoich pracach, iż spadek poziomu religijności jest $\mathrm{w}$ dzisiejszym świecie raczej wyjątkiem niż regułą, oraz że na- 
wet w obszarze kultury zachodniej można było w drugiej połowie XX wieku zaobserwować znaczące symptomy ożywienia religijnego. Z kolei artykuł Adama Wielomskiego stanowi doskonałe wprowadzenie do koncepcji religii politycznych Erica Voegelina oraz teologii politycznej Carla Schmitta. Autor ukazuje w nim, jak wypracowane przez tych filozofów pojęcia analityczne mogą w praktyce pomóc $\mathrm{w}$ odsłanianiu religijnych źródeł struktury i treści danej koncepcji politycznej. Zainteresowanie wspomnianymi autorami zdaje się wciąż utrzymywać w Polsce na wysokim poziomie, o czym świadczą kolejne tłumaczenia ich dzieł1 ${ }^{1}$. Nie znaczy to jednak, że próby aplikacji proponowanego przez nich klucza analitycznego do konkretnych przypadków są w naszym kraju podejmowane często. Z kolei polemice toczącej się między Leo Straussem i Carlem Schmittem tekst poświęcił Łukasz Święcicki.

Mimo sporej rozpiętości ram czasowych oraz różnorodności poruszanej tematyki tom stanowi spójną całość. Dzięki jego lekturze możemy przekonać się, na jak wielu polach badawczych wiedza religioznawcza może otwierać nowe perspektywy, a niejednokrotnie okazuje się po prostu koniecznym warunkiem prowadzenia rzetelnych i trafnych analiz. $Z$ drugiej strony może nam przy niej towarzyszyć poczucie

1 Warto jednak w tym miejscu podkreślić, że praca Politische Religionen Erica Voegelina nie doczekała się jeszcze przekładu na język polski. pewnego niedosytu. W artykułach zawartych w tomie dominują bowiem odniesienia do myśli nacjonalistycznej oraz konserwatywnej. Oczywiście, chociażby w tekście Jacka Bartyzela, obok opisu dziejów meksykańskiego konserwatyzmu i synarchizmu znajdziemy także omówienie tamtejszej odmiany liberalizmu oraz wpływu, jaki wywarły na nią struktury i wartości masonerii. Rafał Łętocha z kolei opisuje chociażby wpływ ewangelikalnego protestantyzmu na politykę USA względem Izraela. Przykłady te pokazują nam, że podejście badawcze proponowane przez autorów ma o wiele szerszy obszar zastosowania niż jedynie idee nacjonalistyczne czy konserwatywne, które w wielu krajach pozostają dziś w niszy. Uzupełnienie tomu o analizę innych przykładów, np. niektórych prądów myśli marksistowskiej, z pewnością pozwoliłoby jednak to przekonanie wzmocnić. Wzorem dla badań wpływu, jaki wywarły na nie rozmaite nurty religijne, mogą być chociażby prace wspomnianego już Erica Voegelina (np. 1992, s. 103-123).

Nie zmienia to jednak faktu, że recenzowany tom jest zdecydowanie godny polecenia, i to z przynajmniej trzech powodów. Po pierwsze, pokazuje na konkretnych przykładach badawczych, jak w praktyce powinno wyglądać, postulowane przez jego redaktorów, uwzględnienie pierwiastka religijnego $\mathrm{w}$ refleksji nad sferą polityki w pełnym znaczeniu tego słowa. Po drugie, zawarte w nim teksty dostarczają wiedzy na tematy, spośród których większość 
nadal pozostaje znana jedynie wąskiemu gronu specjalistów. I co być może najważniejsze - łączy wspomniane refleksje i analizy z nawiązaniami do dorobku tych myślicieli, którzy przekonanie o utrzymującej się wszechobecności wpływów religijnych na sferę polityki przekuli w precyzyjne pojęcia i odpowiedni warsztat badawczy.
BIBLIOGRAFIA:

Voeglin, E. (1992). Nowa nauka polityki. Warszawa: Fundacja „Altheia”. 